Man and Nature

MAN AND NATURE

L'homme et la nature

L'HOMME ET LA NATURE

\title{
Reflections on a Remarkable Performance of Hamlet: A Re-examination of the Hamlet Scene in Goethe's Wilhelm Meisters Lehrjahre
}

\section{Linwood R. Delong}

Volume 5, 1986

URI : https://id.erudit.org/iderudit/1011853ar

DOI : https://doi.org/10.7202/1011853ar

Aller au sommaire du numéro

Éditeur(s)

Canadian Society for Eighteenth-Century Studies / Société canadienne d'étude du dix-huitième siècle

ISSN

0824-3298 (imprimé)

1927-8810 (numérique)

Découvrir la revue

Citer cet article

Delong, L. R. (1986). Reflections on a Remarkable Performance of Hamlet: A Re-examination of the Hamlet Scene in Goethe's Wilhelm Meisters Lehrjahre. Man and Nature / L'homme et la nature, 5, 73-83.

https://doi.org/10.7202/1011853ar

Copyright (c) Canadian Society for Eighteenth-Century Studies / Sociéte canadienne d'étude du dix-huitième siècle, 1986
Ce document est protégé par la loi sur le droit d'auteur. L'utilisation des services d'Érudit (y compris la reproduction) est assujettie à sa politique d'utilisation que vous pouvez consulter en ligne.

https://apropos.erudit.org/fr/usagers/politique-dutilisation/ 


\section{Reflections on a Remarkable Performance of Hamlet: A Re-examination of the Hamlet Scene in Goethe's Wilhelm Meisters Lehrjahre}

Nach dem Tode des alten Hamlet werden die ersteroberten Norweger unruhig. Der dortige Statthalter schickt seinen Sohn Horatio, einen alten Schulfreund Hamlets, der aber an Tapferkeit und Lebensklugheit allen andern vorgelaufen ist, nach Dänemark, auf die Aufrüstung der Flotte zu dringen, welche unter dem neuen, der Schwelgerei ergebenen König nur saumselig von statten geht. ... Der neue König gibt sodann dem Horatio Audienz und schickt den Laertes nach Norwegen mit der Nachricht, dass die Flotte bald anlanden werde, indes Horatio den Auftrag erhält, die Rüstung derselben zu beschleunigen .... ${ }^{1}$

Some readers might not correctly guess the author of this story at first encounter, but these are actually the opening sentences of the plot of Shakespeare's Hamlet, as it is revised and performed by Wilhelm and other members of a small theatre ensemble in Goethe's novel Wilhelm Meisters Lehrjahre. Even by today's standards, where plays are sometimes performed on television with substantial cuts, it is clear that Wilhelm and his ensemble are embarking upon a remarkable, some might add 'highly suspect,' rendering of Shakespeare's famous play. Much has been eliminated, much has been altered.

Goethe's incorporation of Hamlet into this novel functions aesthetically on several levels. One critic has studied the connection between 
Hamlet and the motif of the 'ailing prince' that occurs frequently in the novel. ${ }^{2}$ Others have noticed parallels between characters in Goethe's novel and in Shakespeare's play. ${ }^{3}$ Little attention has been given to the explicit and implicit concept of drama that is contained in Wilhelm's revised version of Hamlet. The purpose of this paper is to examine this revised version of Hamlet as a play, as much as it can be reconstructed, to consider Wilhelm's theory of drama and the interpretation that he brings to Hamlet, and finally to suggest some of the points Goethe wished to make in inserting a discussion and performance of this play into his novel. We shall first examine Wilhelm's interpretation of Hamlet and then consider some of the events that precede Wilhelm's plan to adapt Hamlet for this ensemble.

Wilhelm does not arrive at his interpretation of Hamlet all at once. Rather, he struggles with what at first appear to be serious inconsistencies between the character and utterances of Hamlet. Wilhelm soon concludes that he must consider the indications of Hamlet's character development prior to the death of his father, in order to solve the riddle of Hamlet's inconsistencies. Frankly, Wilhelm invents many biographical details and personality traits. He comes to the conclusion, however, that the young Hamlet must have had a well rounded personality, that he was fairly well educated, socially at ease, neither too idle nor too active, moderate in his love of women, possessed of a keen sense of what is right, willing to tolerate minor insults but opposed to any serious impropriety, scornful of scheming courtiers, but not given to deep-seated hatred. One could regard him as the model of an enlightened eighteenthcentury nobleman.

Later Wilhelm contrasts this picture of equanimity with the image of a prince who feels he has been reduced to a commoner, to a state of nothingness, by the sudden death of his father and the ascent to the throne by his uncle. Wilhelm argues that Hamlet must have been stunned by the sudden remarriage of his mother and, against his real nature, was reduced to a state of deep melancholy. Thus, when he hears the facts concerning his father's death he responds not with thoughts of revolt or revenge, but with a deep sigh: The time is out of joint / 0 cursed spite / That ever I was born to set it right' (I.v.189-90).

Wilhelm concludes with an interpretation that was endorsed by some nineteenth-century critics (notably August Wilhelm Schlegel, Ludwig Tieck, and Samuel Taylor Coleridge) ${ }^{4}$ but has been sharply criticized by other scholars, that Hamlet is the story of a tremendous action placed upon a soul that is not equal to the task, an example of an oak tree placed in a delicate flower pot. Summing up, Wilhelm states, 'ein schönes, reines, edles, höchst moralisches Wesen, ohne die sinnliche Stärke, die 
den Helden macht, geht unter einer Last zugrunde, die es weder tragen noch abwerfen kann ...'(263).

This quotation, which emphasizes Hamlet's moral purity, in sharp contrast to the debauchery at his uncle's court, causes Hamlet to resemble those projections of eighteenth-century moral and social values who, in Enlightenment plays and novels, contrast sharply with the representatives of the degenerate life of the court, be they Emilia Galotti or the shipwrecked residents of Insel Felsenburg.

Hamlet is not only virtuous, he also seems the epitome of beautiful melancholy, the 'süsser Schwermut' that the later eighteenth century savoured with such delight. Hamlet was performed in Germany in the eighteenth century in this vein, and Wilhelm himself refers to Hamlet's 'schwankende Melancholie, seine weiche Trauer, seine tätige Unentschlossenheit'(329). Serlo even suggests that Hamlet should not die at the end of the play, in order to leave the audience with the impression that the melancholy Hamlet could eventually be cured.

In Friedrich Ludwig Schröder's 1776 version of Hamlet ${ }^{5}$ a version with which Goethe was familiar, neither Laertes nor Hamlet dies. Upon discovering that King Claudius is really responsible for most of what happened, and that Hamlet is not guilty of anything, by virtue of temporary insanity, Laertes forgives Hamlet, just as Hamlet forgives his dying mother for her misdeeds.

It should also be noted, however, that Wilhelm delves into Hamlet's character and youth in order to arrive at a typical eighteenth-century solution to Hamlet's seeming inconsistency of character. He works backwards to the specific early experience that, to the eighteenth-century mind, could be used to explain the subsequent behaviour of a person. In Hamlet's case, his melancholia and inability to perform the task required of him are explained by the manner in which a person of his education and temperament reacted to his father's death. The melancholy biography of Aurelie, who attributes her misfortunes to her completely misguided education, forms the backdrop to Wilhelm's discussion of Hamlet, and serves as an example of this linear approach to human psychology.

Finally, one can argue that the young Hamlet and Wilhelm function as representatives of the two basic building blocks of eighteenth-century society that Wilhelm describes to his brother-in-law, Werner. Hamlet, who instinctively displays his fully developed sense of noble status, is an example of the self-confident 'öffentliche Person,' the 'Edelmann, ... [der] durch die Darstellung seiner Person alles gibt.' In one of his first characterizations of Hamlet Wilhelm states, 'der Begriff des Rechts und der fürstlichen Würde, das Gefühl des Guten und Anständigen mit dem 
Bewusstsein der Höhe seiner Geburt, entwickelten sich zugleich in ihm. Er war ein Fürst, ein geborner Fürst ...' (233). This characterization of Hamlet stands in contrast to the image of the common middle-class burgher, the class in which Wilhelm places himself and from which he wishes to escape. This social class has no representative function; it can only strive to become useful and somewhat better educated.

As several critics have noted, ${ }^{6}$ these tidy categories exist more in Wilhelm's mind than in the cross-section of eighteenth-century society that he encounters in the novel. Nevertheless, Wilhelm is quite willing to project the aristocratic half of his typology of society onto Shakespeare's play and then to experience an aristocratic existence vicariously by playing the role of Hamlet.

A subsequent discussion between Wilhelm and Serlo, the director of the ensemble, introduces a totally different aspect of Shakespeare's play, the question of its structure. Serlo makes the rather bald assertion that Hamlet essentially falls apart after the third act, even in the opinion of English theatregoers. Wilhelm replies, 'der Held hat keinen Plan, aber das Stück ist planvoll' (273). He buttresses this assertion with the argument that Hamlet is a play in which an incredible deed drives forward to its own inevitable conclusion, dragging guilty and innocent persons alike with it. In the end, a whole family is destroyed. Wilhelm argues that every violent misdeed leads to these results.

Wilhelm's reply is noteworthy, because it is reminiscent of an observation contained in Goethe's 1771 essay 'Zum Schäkespears Tag':

[Shakespeares] Plane, sind, nach dem gemeinen Styl zu reden, keine Plane, aber seine Stücke, drehen sich alle um den geheimen Punckt ... in dem das Eigenthümliche unsres Ich's, die prätendirte Freyheit unsres Wollens, mit dem nothwendigen Gang des Ganzen zusammenstösst. ${ }^{7}$

In both instances an examination of Shakespeare's plays reveals that there is a seeming lack of structure, but also that there is an underlying fidelity to the real relationship between individual freedom (for example the king's seeming ability to escape punishment for having murdered his brother), and the power of Fate. In 'Zum Schäkespears Tag' Goethe demonstratively rejects eighteenth-century French critics who demand adherence to the famous 'three unities,' and discovers a much more profound unity of overall conception in Shakespeare's plays. In this novel Wilhelm pushes aside Serlo's criticism of the disjointedness of the fourth and fifth acts of Hamlet and argues that if one sets aside the usual expectations of a vigorous hero who can triumph over tremendous odds, one can discover an underlying unity of action in the play as a whole. 
To make this unity more discernible, however, Wilhelm feels obliged to alter some of the details of the plot and to eliminate some of the supporting characters. Let us examine more closely Wilhelm's revised version of Hamlet and the arguments he advances for making these revisions. Wilhelm plans to delete all references to the young Fortinbras and his uncle; Horatio's return from Wittenberg and Hamlet's desire to go there; Laertes' journey to France and his return; the decision to send Hamlet to England; Hamlet's capture by the pirates; the letter of commission that Rosencrantz and Guildenstern take with them and their subsequent deaths at Hamlet's hand.

It should be noted that Wilhelm does not regard all of these supporting characters as unessential - he recognizes that Shakespeare's original version requires many of them - but he feels they are undramatic and novelistic, because they draw attention away from the central theme: the consequences of the murder of Hamlet's father. In his revised version Wilhelm wishes to retain all the important structural features of the play, 'die grossen innern Verhältnisse der Personen und der Begebenheiten, die mächtigen Wirkungen, die aus den Charakteren und Handlungen der Hauptfiguren entstehen' (317), but to simplify the overall plot. Wilhelm's new version focuses on Hamlet's desire to avenge the murder of his father and compresses the various subplots into one: the king's decision to send a Danish fleet to Norway, to quell an uprising there. As the quotation given at the beginning of this paper shows, the king is slow to act on the uprising in Norway and must be prodded into action by Horatio. Upon Horatio's arrival in Denmark Hamlet confides to him that his father has been murdered. Horatio advises Hamlet to use the Danish fleet to his own advantage: to travel with the fleet to Norway and to mobilize the Norwegian army against his uncle. The fleet is held back by unfavourable winds, however, and Hamlet, whose secret ambitions are discerned by his uncle, is secretly murdered while participating in jousts with Laertes. True to Shakespeare's original, the king, queen, and Laertes also die.

In revising Shakespeare's play in this manner Wilhelm accomplishes other things. He eliminates one of the play's most aggressive characters, Fortinbras. He softens Hamlet's intellectual urges (in particular his desire to return to Wittenberg), but he also removes the one act that could have put Hamlet out of action entirely: the king's decision to send him to England where he is to be put to death.

With Fortinbras removed, Hamlet's seeming lack of aggression and assertion are less obvious. Because Hamlet is never sent away, he can appear to be constantly pursuing his plan of revenge at the court. Rosencrantz and Guildenstern are retained in the revised version - they are 
probably supposed to murder Hamlet on the way to Norway - but the fleet never sails. Horatio also undergoes a transformation: he is described as '[ein alter] Schulfreund Hamlets, der aber an Tapferkeit und Lebensklugheit allen andern vorgelaufen ist'(319). Significantly it is Horatio whom Hamlet appoints as his successor in the last scene of the play. It is unclear whether Wilhelm would retain all of Hamlet's attempts to verify the truth of the ghost's message before he undertakes any decisive action against his uncle. Taking the plot summary of Wilhelm's version at face value, Hamlet appears to be certain of his motives, intent on realizing them, but at the end of the play, a victim of Fate.

In Wilhelm's mind his revised version of Hamlet adheres closer than Shakespeare's version to the essential qualities of a play. In a discussion with members of his ensemble Wilhelm argues that a successful play focuses on characters and decisive actions, rather than on personal reflections and events, which are the mainstay of the novel. A tragedy should make full use of Fate, the force that drags humans unconnected with each other to unforeseen catastrophes, Wilhelm maintains. He concedes that Hamlet contains a high percentage of personal reflections and events, but he claims that these novelistic qualities are overshadowed by the supreme power of Fate, which forces Hamlet into his tragic death. As Eric Blackall has shown, Wilhelm's distinctions between play and novel are loosely based on Aristotle. ${ }^{8}$

Clearly Wilhelm's version deprives the play of much of its subtlety, but it renders it somewhat more Aristotelean through the increased emphasis on plot - the consequences of a murder - rather than on character delineation. Aristotle states, 'You could not have a tragedy without action, but you can have one without character-study.' ${ }^{\prime}$

In emphasizing Fate as much as he does, Wilhelm also shifts the focus away from Hamlet's alleged inability to fulfill his personal mission. Serlo reinforces this shift with his assertion that the play is primarily about the tragic downfall of a whole royal dynasty, caused by internal intrigues and criminal acts (321). It is as if Hamlet has become a 'better' tragic hero, in the sense that he now begins to resemble archetypal Greek tragic heroes, even if he also embodies certain eighteenth-century social values. Wilhelm's version is certainly more convincing than Schröder's version, which eliminates many of the same characters and scenes that Wilhelm removes, but transforms the play into a simplistic tale of an evil king and queen being punished and an innocent Hamlet and a noble Laertes being reconciled.

In revising Hamlet in this fashion Wilhelm has accomplished something else: he has provided a possible answer to the frequent criticism of Shakespeare's plays, by eighteenth-century critics, that they 
lack form and structure. Jarno, the person who first brings Shakespeare to Wilhelm's attention, also mentions the lack of form in Shakespeare's plays. By retaining what he believes are all the essential features of the plot and altering only the backdrop of the play, Wilhelm claims to show that the play does have an inherent unity of conception and that there is consistent character development. Wilhelm's 'improvements' to the text simply make these basic qualities more readily visible. It is as if Wilhelm were following a program set out by Lessing in his seventeenth 'Literaturbrief':

Wenn man die Meisterstücke des Shakespeare, mit einigen bescheidenen Veränderungen, unsern Deutschen übersetzt hätte, ich weiss gewiss, es würde von bessern Folgen gewesen sein, als dass man sie mit Corneille und Racine so bekannt gemacht hat ... Nach den Mustern der Alten ... zu entscheiden, ist Shakespeare ein weit grösserer tragischer Dichter als Corneille ... Der Engländer erreicht den Zweck der Tragödie fast immer, so sonderbare und ihm eigene Wege er auch wählet; und der Franzose erreicht ihn fast niemals, ob er gleich die gebahnten Wege der Alten betritt. ${ }^{10}$

But, one may ask, does Wilhelm contrast Shakespeare with Racine and Corneille? Not in so many words, but the comparison between Shakespeare and French classical drama is still unmistakably present in the text. Let us examine the relationship of Hamlet to the numerous other plays and theatre experiences mentioned in Wilhelm Meisters Lehrjahre.

In the period between his earliest experiments with marionettes and his performance of the role of Hamlet, Wilhelm is exposed to an incredible variety of plays and performance styles: his own youthful dramatic renditions of Bible stories, plays from Gottsched's anthology Die deutsche Schaubühne, 'Ritterromane' adapted for the stage, tightrope walkers and circus acts, impromtu plays, allegorical plays in honour of a visiting prince, primitive situation comedies: the list could be extended further. Within this amorphous collection, however, one can detect a certain historical development: simple religious plays in the tradition of medieval mystery plays, Baroque 'Haupt-und Staatsaktionen,' complete with the Hanswurst character, French classicism, as represented by references to Racine and Corneille, 'Ritterstücke' (reminiscent of Goethe's own Götz von Berlichingen), and the 'bürgerliches Trauerspiel,' as illustrated by Lessing's Emilia Galotti.

Most of these plays fare badly within this novel. In his marionette theatre Wilhelm usually only performs the fifth act of a play, in which the tragic hero is stabbed to death. The theatre troupe that, together with Wilhelm, performs for the baron consists of inexperienced actors who 
play stock roles and habitually make drastic alterations to the texts. None of the plays of the French classicists are actually performed in the novel. However, when Wilhelm begins a speech to the prince praising the plays of Racine and Corneille, the prince, an admirer of these playwrights, turns away and pays no attention. The prince must content himself with the performance of a contrived, allegorical play in which he is shown triumphing over the forces of violence and discord.

Thus, shortly after the period when Lessing had vented his full wrath against Gottsched and other proponents of French classicism and had frequently praised Shakespeare, Goethe's wandering protagonist by contrast wanders past French classicism, becomes totally absorbed by Shakespeare, and decides to perform the role of Hamlet. Wilhelm tries to ingratiate himself with the prince by praising Racine, the playwright of nobility. When he begins to read Shakespeare, he has no need for ingratiating praise. Shakespeare seizes Wilhelm's emotions powerfully, because his plays uncover the meaning of life itself. In them Wilhelm rediscovers all his own intuitions about mankind and Fate.

Critics have recognized that Wilhelm's 'discovery' of Shakespeare in this novel has many points of similarity with Goethe's reappreciation of Shakespeare during his Strasbourg 'Sturm und Drang' years. Wilhelm's enthusiastic praise, his feelings of new insight, 'man glaubt vor den aufgeschlagenen ungeheuren Büchern des Schicksals zu stehen, in denen der Sturmwind des bewegtesten Lebens saust, und sie mit Gewalt rasch hin und her blättert' (205) are reminiscent of Goethe's own remarks in 'Zum Schäkespears Tag':

Die erste Seite die ich in ihm las, machte mich auf Zeitlebens ihm eigen, und wie ich mit dem ersten Stücke fertig war, stund ich wie ein blindgebohrner, dem eine Wunderhand das Gesicht in einem Augenblicke schenckt.(123)

This should not lead to the conclusion that Goethe is using Wilhelm as a mouthpiece for his own interpretation of Hamlet. Within the novel Wilhelm's theatrical ambitions emerge as a mistake, albeit a productive one. Wilhelm's belief that his motley assortment of actors are contributing to the development of a national German theatre (231), his conviction that in studying Shakespeare he is making progress in the 'real world,' his tendencies toward self-delusion (225), to which the narrator frequently refers, all create a distance between Goethe and his protagonist.

Goethe is borrowing on the 'Sturm und Drang' rediscovery of Shakespeare, but is revising this phenomenon somewhat. To Herder, Shakespeare's plays were emotionally powerful, but chaotic in form: 
Wie vor einem Meere von Begebenheit, wo Wogen in Wogen rauschen, so tritt vor [Shakespeares] Bühne. Die Auftritte der Natur rücken vor und ab; würken in einander, so Disparat sie scheinen; bringen sich hervor, und zerstören sich, damit die Absicht des Schöpfers, der alle im Plane der Trunkenheit und Unordnung gesellet zu haben schien, erfüllt werde. ..... ${ }^{11}$

As we have seen, Wilhelm's equally emotional first reading of Shakespeare gives way to the discovery of what he believes is a way to restructure this 'sea of events' into a coherent whole with logical character development, while ostensibly remaining faithful to the intent of Shakespeare's version.

In studying Shakespeare, Wilhelm learns (or claims to learn) to appreciate a play as an organic unit. When he first studies the role of Hamlet (231-2), he concentrates on the monologues and other significant passages that reveal Hamlet's temperament. It becomes clear to him that approaching the play on the basis of selected passages alone is unsatisfactory. Wilhelm's elucidation of the evolution of Hamlet's character from his youth to his first appearance in the play is an attempt, however speculative, to penetrate to the true intentions of the playwright, 'in den Geist des Schriftstellers einzudringen' (234). He admonishes the rest of the cast to study their plays in a similar manner. This contrasts with Wilhelm's earlier practice, for example at the baron's castle:

besonders war das Streichen eine seiner angenehmsten Beschäftigungen, wodurch er ein jedes Stück auf das gehörige Zeitmass herunter zu setzen wusste, ohne irgend eine andere Rücksicht zu nehmen.(166)

Wilhelm wishes not only to grasp the true meaning of the characters in a play, but also to perform the plays as the author intended them. It is Wilhelm's original intention to perform Hamlet with no cuts at all. He prevails, at least in part, against Serlo, who believes that most plays, including Shakespeare's, have no aesthetic unity and should be cut to separate the wheat from the chaff.

In deciding on a revised version of Hamlet Wilhelm tries to improve upon the performance practices of his day. He includes the traditionally central characters and events, 'die niemand anzutasten wagt, ...und die man, wie ich höre, beinahe alle auf das deutsche Theater gebracht hat'(318). But he refuses to simply exclude the supporting characters and subplots,' [die man] für allzu unbedeutend angesehen, nur im Vorbeigehn davon gesprochen, oder ... gar weggelassen hat'(318). Wilhelm's revised version of Hamlet reflects his recognition that the play must be understood and performed as an aesthetic whole. 
In effect, Goethe shows us a talented, idealistic, somewhat misguided theatre enthusiast struggling with his director to harmonize Aristotelean concepts of drama and eighteenth-century concepts of psychology and class structure with a famous Renaissance play. Goethe would probably have made substantial cuts to Shakespeare's play himself, judging by his remarks about the sanctity of Shakespeare's text in a much later essay entitled 'Shakespeare und kein Ende.' There Goethe specifically cites Schröder's version of Hamlet as an example to follow. ${ }^{12}$ The focus in this novel is not on Goethe but on Wilhelm Meister, and briefly, on the tremendous impact of Hamlet on Wilhelm. Perhaps Goethe's real tribute to this play is that it withstands Wilhelm's attempts to 'improve' it: the first performance, with Wilhelm in the leading role, is a resounding success.

LINWOOD R. DELONG

University of Winnipeg

\section{NOTES}

1 Johann Wolfgang Goethe, Wilhelm Meisters Lehrjahre. Vol. 7 of Gedenkausgabe der Werke, Briefe und Gespräche (Zürich: Artemis 1948) 319. All references to Wilhelm Meister are to this edition.

2 David Roberts, The Indirections of Desire: Hamlet in Goethe's 'Wilhelm Meister' (Heidelberg: Winter 1980)

3 Mark Evan Bonds, 'Die Funktion des "Hamlet"-Motivs in Wilhelm Meisters Lehrjahren,' Goethe Jahrbuch 96 (1979) 101-10

4 William Diamond, 'Wilhelm Meister's Interpretation of Hamlet,' Modern Philology 23 (1925), 90

5 Friedrich Ludwig Schröder, Hamlet, Prinz von Dänemark: ein Trauerspiel in fünf Aufzügen nach Shakespeare: aus dem Jahre 1776, in Die Aufnahme Shakespeares auf der Bühne der Aufklärung in den sechziger und siebziger Jahren, ed, F. Brüggemann. Deutsche Literatur: Sammlung literarischer Kunst-und Kulturdenkmäler in Entwicklungsreihen: Reihe Aufklärung, Bd. 11. (Leipzig: Phillipp Reclam 1937), 165-233

6 Eric A. Blackall, Goethe and the Novel (Ithaca, NY:Cornell University Press 1976), 126-7, and Stefan Blessin, Die Romane Goethes (Königstein/Ts.:

Athenäum 1976), 16

7 Johann Wolfgang Goethe, 'Zum Schäkespears Tag' in Der junge Goethe. Vol. 4 of Gedenkausgabe der Werke, Briefe und Gespräche (Zürich: Artemis 1949), 124 
8 Blackall, 80-1

9 Aristotle, The Poetics, trans. W. Hamilton Fyfe (Cambridge, MA: Harvard University Press 1973), ch. 6

10 Gotthold Ephraim Lessing, Briefe, die neueste Literatur betreffend, ed. Wolfgang Bender (Stuttgart: Reclam 1972), 50

11 Johann Gottfried Herder, 'Shakespeare,' in Sämtliche Werke, ed. Bernhard Suphan (1891; rpt. Hildesheim: Georg Olms 1967), V, 220

12 Johann Wolfgang Goethe, 'Shakespeare und kein Ende,' in Schriften zur Literatur. Vol. 14 of Gedenkausgabe der Werke, Briefe und Gespräche (Zürich: Artemis 1949), 768 